\title{
Photoperiod-dependent regulation of inhibin in Siberian hamsters: I. Ovarian inhibin production and secretion
}

\author{
H A Kenny ${ }^{1}$, D J Bernard ${ }^{1}$, T H Horton ${ }^{1}$ and T K Woodruff ${ }^{1,2}$ \\ ${ }^{1}$ Department of Neurobiology and Physiology, Northwestern University, Evanston, Illinois 60208, USA \\ ${ }^{2}$ Department of Medicine, Northwestern University Medical School, Chicago, Illinois 60611, USA \\ (Requests for offprints should be addressed to T K Woodruff, 2145 North Sheridan Road, OT Hogan Hall, Room 4-150, Department of Neurobiology and \\ Physiology, Northwestern University, Evanston, Illinois 60208, USA; Email: tkw@northwestern.edu) \\ (D J Bernard is now at Population Council, New York, New York 10021, USA)
}

\begin{abstract}
Follicle-stimulating hormone (FSH) stimulates ovarian follicle development and the production of protein hormones including inhibin $\mathrm{A}$ and inhibin $\mathrm{B}$. The inhibins are dimeric proteins $\left(\alpha-\beta_{\mathrm{A}}\right.$ or $\left.\alpha-\beta_{\mathrm{B}}\right)$ secreted by growing follicles that suppress FSH in a classical endocrine negative feedback loop. Siberian hamsters, Phodopus sungorus, exhibit seasonal variation in FSH levels. Given the role of inhibin in FSH regulation, we hypothesized that ovarian inhibin expression differs between animals reared in long (16 h light: $8 \mathrm{~h}$ darkness) and short (6 h light:18 h darkness)
\end{abstract}

photoperiods. To examine inhibin expression in animals housed under long or short photoperiods, hamster inhibin $\alpha-, \beta_{\mathrm{A}^{-}}$, and $\beta_{\mathrm{B}^{-}}$subunits were cloned and used to detect and localize inhibin subunit mRNA in developing follicles. Ovarian inhibin $\alpha$-subunit mRNA levels were significantly higher in long day-exposed (LD) than in short day-exposed (SD) hamsters. In addition, dimeric inhibin, as well as inhibin $\alpha_{-}, \beta_{\mathrm{A}^{-}}$, and $\beta_{\mathrm{B}}$-subunit protein levels were higher in the LD than in the SD hamster ovaries.

Journal of Endocrinology (2002) 174, 71-83

\section{Introduction}

The inhibins are dimeric protein hormones produced by developing ovarian follicles that in many species inhibit the secretion of follicle-stimulating hormone (FSH) from pituitary gonadotropes (Woodruff et al. 1988). Inhibin A and inhibin $\mathrm{B}$ share a common $\alpha$-subunit that assembles with one of two highly related $\beta$ subunits $\left(\beta_{\mathrm{A}}\right.$ or $\beta_{\mathrm{B}}$ ) to form the active hormones. All three subunits are stimulated by FSH and are initially synthesized as pre-prohormones. The biologically active form of the ligands is a dimer of the C-terminal regions of the subunits linked by a single intermolecular disulfide bond (Hsueh et al. 1987, Rivier et al. 1987). Inhibin A and inhibin B are thought to inhibit FSH release similarly; however, the pattern of secretion for each ligand differs during the reproductive cycle. The synthesis and secretion of the inhibins are best characterized during the rat estrous cycle (Woodruff et al. 1996, Bernard \& Woodruff 2001). At the onset of a new cycle, inhibin A and inhibin B levels increase in the follicle population that has been recruited by the so-called 'secondary' FSH surge. FSH levels fall in response to rising inhibins. Estradiol is not produced in measurable levels in this early phase of the cycle, suggesting that the inhibition of FSH is reliant largely on ovarian inhibin (Woodruff et al. 1996, Bernard \& Woodruff 2001). Inhibin B rises much more quickly and reaches maximal levels during the early follicular phase (metestrus, diestrus). Inhibin A rises more slowly and closely parallels the rise in estradiol secretion from the Graafian follicles. All three inhibin subunits produced in the Graafian follicles are inhibited by the preovulatory surges of the gonadotropins which also induce follicle degradation prior to ovulation. The half-lives of the subunit mRNAs and the ligands are short. Thus, as a consequence of FSH and luteinizing hormone ( $\mathrm{LH})$ action, inhibin A and inhibin B levels fall (Woodruff et al. 1993a,b, Halvorson et al. 1994, Weiss et al. 1995, Winters et al. 1996). The pituitary is thereby relieved from inhibin repression and elevated FSH levels persist, leading to recruitment of a new cohort of follicles into the next cycle.

The $\beta$-subunits can also self-assemble into dimeric proteins, which are antagonists to inhibin action. Activin $\mathrm{A}\left(\beta_{\mathrm{A}}-\beta_{\mathrm{A}}\right)$, activin $\mathrm{B}\left(\beta_{\mathrm{B}}-\beta_{\mathrm{B}}\right)$ and activin $\mathrm{AB}\left(\beta_{\mathrm{A}}-\beta_{\mathrm{B}}\right)$ have all been purified from follicular fluid (Ling et al. 1986a,b, Schmelzer et al. 1990, Robertson et al. 1992, Yokoyama et al. 1995). Activin A has been detected in the serum of animals at the time of the preovulatory and secondary FSH surges in rats, but at no other time does activin appear to circulate at detectable levels (Besecke et al. 1997). Thus, the differential production of inhibins or activins must be exquisitely controlled at the cellular level to ensure the secretion of the appropriate ligand at specific times during the cycle. Relatively little is known regarding the mechanism(s) underlying dimer assembly, processing, or 
Table 1 Inhibin oligonucleotides used for RT-PCR amplification of hamster inhibin subunit cDNAs. The oligonucleotide sequences and the location and source of these sequences are listed

\begin{tabular}{|c|c|c|c|}
\hline \multirow[b]{2}{*}{ Oligo } & Sequences & Sequence no. & $\begin{array}{l}\text { GenBank } \\
\text { accession no. }\end{array}$ \\
\hline & & & \\
\hline$\alpha 5^{\prime}$ & TGTCCTGGCCAAAGTGARGGC & $345-365^{*}$ & NM012590 \\
\hline$\alpha 3^{\prime}$ & CAGGAAAGGAGTGGTCTCAGG & $888-903$ & NM012590 \\
\hline$\beta_{\mathrm{A}} 5^{\prime}$ & CTCATGGAGCAGACCTCGGAG & $508-528$ & NM017128 \\
\hline$\beta_{\mathrm{A}} 3^{\prime}$ & GTGAGGATGGTCTTCAGACTG & 1024-1044 & NM017128 \\
\hline$\beta_{B} 5^{\prime}$ & TATGTCCTGGAGAAGGGCAGC & $422-1220$ & XM046786 \\
\hline$\beta_{\mathrm{B}} 3^{\prime}$ & GCGATGTCTGCTATCGCCCAG & 1200-1220 & XM046786 \\
\hline
\end{tabular}

*The $\alpha$-subunit forward primer was modified at nucleotide 18 after unsuccessful amplification and sequence comparison of multiple species $\alpha$-subunit cDNA sequences.

secretion; thus, it is necessary to identify animal models that will permit a more detailed analysis of each of these processes. Towards that end, we have investigated the regulation of inhibin and activin in the Siberian hamster (Phodopus sungorus).

Siberian hamsters exhibit seasonal variation in FSH levels. These changes can be recapitulated in laboratory animal breeding colonies by altering daily light exposure (Schlatt et al. 1993). Because follicle development can be inhibited by movement of the animals from long to short photoperiods (Lerchl \& Schlatt 1993, Schlatt et al. 1993), we predicted that the regulation of inhibin subunit assembly could be readily examined in this animal model. Moreover, given the role of inhibin in FSH regulation, we hypothesized that ovarian inhibin production would differ between long day-exposed (LD) and short day-exposed (SD) animals. Significantly, ovarian inhibin synthesis does differ between LD and SD animals, with more overall inhibin production in ovaries collected from LD animals. In a companion paper (Kenny et al. 2002), we demonstrate that FSH is not the only stimulus necessary to stimulate inhibin, suggesting that the production and assembly of inhibin A and inhibin B relies on additional cues that have not yet been identified.

\section{Materials and Methods}

\section{Animals and experimental procedures}

Female Siberian hamsters (21-32 g, 53-60 days of age) were bred at Northwestern University and were individually housed in access-controlled rooms isolated from males. Food and water were available ad libitum and light cycles of $16 \mathrm{~h}$ light: $8 \mathrm{~h}$ darkness (LD) or $6 \mathrm{~h}$ light: $18 \mathrm{~h}$ darkness (SD) were provided. The ovaries were collected from animals after asphyxiation in a $\mathrm{CO}_{2}$ chamber. The tissue was stored at $-80{ }^{\circ} \mathrm{C}$ until further processed. Blood obtained by cardiac puncture was allowed to clot on ice for
$2 \mathrm{~h}$ and serum was separated and stored at $-80{ }^{\circ} \mathrm{C}$ in assay-specific aliquots. All animals were treated in accordance with the NIH Guide for the Care and Use of Laboratory Animals

Cloning of hamster inhibin $\alpha-, \beta_{A^{-}}$and $\beta_{B^{-}}$subunits: $c D N A$ library screening, $R T-P C R$, and $5^{\prime}-R A C E$

Siberian hamster ovarian total RNA was extracted and was reverse transcribed into cDNA using Maloney murine leukemia virus reverse transcriptase in the presence of random hexamer oligonucleotides and deoxynucleotide triphosphates (dNTPs) (Promega Corp., Madison, WI, USA). PCR was performed on the RT reaction using standard techniques and inhibin $\alpha_{-}, \beta_{\mathrm{A}^{-}}$and $\beta_{\mathrm{B}^{-}}$subunitspecific primers which were initially generated from rat inhibin subunit sequences with the exception of the $\alpha$-subunit forward primer, which was modified after unsuccessful amplification and sequence comparison of multiple species $\alpha$-subunit cDNA sequences. All primers used to amplify the inhibin subunits from Siberian hamster ovarian RNA are listed in Table 1. PCR products were cloned into pCRScript vector (Stratagene, La Jolla, CA, USA), and sequenced with T7 and T3 primers using BigDye Terminator Cycle Sequencing (ABI Prism, Foster City, CA, USA). The hamster $\alpha$-subunit cDNA sequence was $88 \%, 87 \%$ and $84 \%$ identical to orthologous sequences in mouse, rat and human respectively. The amplified hamster $\alpha$-subunit cDNA was $559 \mathrm{bp}$ in length and corresponds to signal peptide sequence, nucleotides 345 to 903 of the rat $\alpha$-subunit sequence (GenBank accession number NM012590). The hamster $\beta$-subunits cDNAs were sequenced and $\beta_{\mathrm{A}}$ was $95 \%, 95 \%$ and $92 \%$ and $\beta_{\mathrm{B}}$ was $92 \%, 91 \%$ and $89 \%$ identical to the mouse, rat and human orthologs respectively. The hamster $\beta_{\mathrm{A}}$-subunit was $563 \mathrm{bp}$ in length and corresponds to signal peptide sequence, base-pairs 508 to 1044 of the rat $\beta_{\mathrm{A}}$-subunit sequence (GenBank accession number NM017128). The 
amplified hamster $\beta_{\mathrm{B}}$-subunit was $800 \mathrm{bp}$ in length and corresponds to signal peptide sequence and mature peptide sequence, nucleotides 422 to 1220 of human $\beta_{\mathrm{B}}$-subunit sequence (GenBank accession number XM046786).

The inhibin $\alpha$-subunit fragment generated above was random prime labeled and used to screen a Siberian hamster ovarian cDNA library (ZAP-cDNA synthesis kit, Stratagene) using standard techniques. The in vivo excised clones were sequenced with T7 and T3 as described above. All sequences were aligned using Sequencher (version 3.1.1, Gene Codes Corp., Ann Arbor, MI, USA) on a Macintosh G3 computer (Apple, Cupertino, CA, USA). The $5^{\prime}$ end of the cloned Siberian hamster inhibin $\alpha$-subunit was $242 \mathrm{bp}$ downstream of the putative start site of translation when compared with the rat inhibin $\alpha$-subunit sequence (GenBank accession number NM012590). Therefore, to obtain additional 5 '-sequence we used RLM-RACE following the manufacturer's instructions (Ambion Inc., Austin, TX, USA). The openreading frame (ORF) of the hamster $\alpha$-subunit nucleotide sequence was $88 \%, 89 \%$ and $81 \%$ identical to mouse, rat and human respectively.

\section{RNA isolation and Northern blot analysis}

Total RNA was extracted from ovarian tissue collected from female Siberian hamsters housed in short or long photoperiods using TRIZOL Reagent (Life Technologies Inc., Rockville, MD, USA). Concentration of the isolated RNA was determined by absorption at $260 \mathrm{~nm}$ on a spectrophotometer and the integrity of the preparation examined by agarose gel electrophoresis. For RNA blot analysis, $20 \mu \mathrm{g}$ total RNA were electrophoresed per lane on a $1.0 \%$ agarose, $1.1 \mathrm{M}$ formaldehyde and $1 \times(3-[\mathrm{N}-$ Morpholino]propane sulfonic acid) (MOPS) using standard procedures. RNA was transferred to Hybond $\mathrm{N}$ nylon membranes (Amersham) by capillary action overnight with $20 \times$ SSC. Radiolabeled cDNA probes were synthesized from plasmid DNA templates using deoxycytidine $5^{\prime}$-triphosphate $\left[\alpha-{ }^{32} \mathrm{P}\right] 3000 \mathrm{Ci}(111 \mathrm{TBq}) / \mathrm{mmol}$ (NEN Life Sciences Products, Boston, MA, USA) and Ready-to-Go beads (-dCTP) (Amersham). The membranes were hybridized to $\alpha, \beta_{\mathrm{A}}$ and $\beta_{\mathrm{B}}$ probes in hybridization buffer $(50 \%$ formamide, $5 \times$ SSC, $20 \mathrm{mM}$ $\mathrm{NaH}_{2} \mathrm{PO}_{4}$ (pH 6.8), 1\% SDS, $5 \%$ dextran sulfate, and $100 \mu \mathrm{g} / \mathrm{ml}$ herring sperm DNA). After hybridization, the blots were washed sequentially in $2 \times \mathrm{SSPE}+0.5 \% \mathrm{SDS}$ at $20{ }^{\circ} \mathrm{C}, 2 \times \mathrm{SSPE}+0.5 \%$ SDS at $65^{\circ} \mathrm{C}$ and $0.2 \times$ SSPE $+0 \cdot 1 \%$ SDS at $65^{\circ} \mathrm{C}$. First, the blots were exposed to a Phosphor screen (Molecular Dynamics, Piscataway, $\mathrm{NJ}$, USA) for $4 \mathrm{~h}$ and analyzed using STORM (Molecular Dynamics) and Image Quant (Molecular Dynamics). The optical densities for $\alpha-, \beta_{A^{-}}$and $\beta_{B^{3}}$-subunits were normalized by dividing the optical density for RPL19 in the same lane. Secondly, the blots were exposed to X-OMAT film (Eastman Kodak) for 2 to 6 days.

\section{In situ hybridization}

Fresh frozen ovaries were sectioned $(20 \mu \mathrm{m})$ on a Leica CM3050 cryostat (Deerfield, IL, USA). Alternate sections were mounted on six microscope slides. Slides were labeled for hybridization to $\alpha, \beta_{\mathrm{A}}$ and $\beta_{\mathrm{B}}$ sense and $\alpha, \beta_{\mathrm{A}}$ and $\beta_{\mathrm{B}}$ anti-sense probes. Cross-sections of the ovary were taken with respect to the attached oviduct to maintain a standard orientation between samples. Sections were fixed in $4 \%$ paraformaldehyde, treated with $0 \cdot 2 \%(\mathrm{v} / \mathrm{v})$ acetic anhydride in $0.1 \mathrm{M}$ triethanolamine for $10 \mathrm{~min}$, dehydrated through an ethanol series $(50 \%, 70 \%, 95 \%$ and $100 \%)$, and stored in a vacuum dessicator until further processed $(<18 \mathrm{~h})$. cRNA probes (sense and anti-sense riboprobes) were synthesized from linearized plasmid DNA templates using T7 or T3 RNA polymerase and easy tides uridine $5^{\prime}$-triphosphate $\left[\alpha-{ }^{32} \mathrm{P}\right] 3000 \mathrm{Ci}$ (111 $\mathrm{TBq}) / \mathrm{mmol}$ (NEN Life Sciences). A coverslip was placed on the slide after addition of the hybridization solution (50\% formamide, $0.3 \mathrm{M} \mathrm{NaCl}, 0.01 \mathrm{M}$ Tris, $1 \mathrm{mM}$ EDTA, $1 \times$ Denhardt's, $20 \%$ dextran sulfate, $500 \mu \mathrm{g} / \mathrm{ml}$ tRNA, $500 \mu \mathrm{g}$ polyA RNA, and $1 \times 10^{8}$ c.p.m. $/ \mathrm{ml}{ }^{32} \mathrm{P}-$ labeled probe) and hybridized for $18 \mathrm{~h}$ at $42{ }^{\circ} \mathrm{C}$ in heavy mineral oil, as previously described (Woodruff et al. 1987, 1989). Oil and coverslips were removed, and the sections were treated with $20 \mu \mathrm{g} / \mathrm{ml}$ RNase-A for $1 \mathrm{~h}$ at $37^{\circ} \mathrm{C}$. After RNase treatment, the slides were washed sequentially in $2 \times, 1 \times$ and $0.5 \times \mathrm{SSC}$ for $2 \mathrm{~h}$ at $42^{\circ} \mathrm{C}$. Slides were exposed to Biomax film (Eastman Kodak) for $6 \mathrm{~h}$ and subsequently prepared for autoradiography using Kodak NTB-2 emulsion. Slides were exposed to the emulsion for 2 weeks and developed using D-19 developer and fixer (Eastman Kodak). Processed tissues were stained with hematoxylin and silver grains were visualized using a Nikon Eclipse E600 (Nikon Instruments Inc., Melville, NY, USA). Digital images were captured using Metamorph (v4.6; Universal Imaging Corp, Downingtown, PA, USA). Three or four animals were analyzed for each treatment.

\section{Hormone assays}

Serum FSH levels were determined in duplicate by RIA with NIH-FSH RP-2 (NIDDK, Rockville, MD, USA) as standard, and anti-rat (r) FSH-I-8 as trace (Northwestern University RIA Core). The limit of detection in the assay was $2 \mathrm{ng} / \mathrm{ml}$ with inter- and intra-assay variations of $5 \cdot 22 \%$ and $4 \cdot 15 \%$ respectively. Serum LH levels were determined in duplicate by RIA with NIH-LH RP-3 (NIDDK) as standard and anti-rLH-S-11 as trace (Northwestern University RIA Core). The limit of detection in the assay was $0.2 \mathrm{ng} / \mathrm{ml}$ with inter- and intra-assay variations of $11.5 \%$ and $9.6 \%$ respectively. Inhibin A, inhibin B and activin A assay kits were purchased from Serotec (Oxford, Oxon, UK), and the characteristics of these dimer-specific assays have been described previously 
(Groome \& Lawrence 1991, Groome et al. 1994, 1996, Knight et al. 1996, Muttukrishna et al. 1996). Serum and ovarian inhibin A, inhibin B and activin A levels were determined in duplicate. Each ovarian sample was obtained by homogenizing one ovary in $0.5 \mathrm{ml} 0.85 \%(\mathrm{w} / \mathrm{v})$ $\mathrm{NaCl}$ as described (Herath et al. 2001). The homogenized samples were centrifuged at $15000 \times \boldsymbol{g}$ for $20 \mathrm{~min}$ at $4{ }^{\circ} \mathrm{C}$. Inhibin A and inhibin B assays were performed on freshly homogenized tissue. The inhibin assays were validated within the laboratory using recombinant human (rh) inhibin A, rh-inhibin B and Siberian hamster serum. The inhibin A standard was the WHO standard (91/624). The inhibin B standard was from National Institute for Biological Standards and Control (NIBSC). No crossreactivity between heterologous ligands occurred using purified recombinant ligands for any of the assays. Rh-ligands were spiked at three dilutions into serum from ovariectomized female Siberian hamsters. Inhibin A recovery was 75, 82 and $80 \%$ for high, medium and low standards and inhibin B recovery was 90,87 and $86 \%$ for high, medium and low standards. Native Siberian hamster ligands diluted linearly and in parallel to the standard curve (data not shown). The assays were sensitive $(7 \cdot 8 \mathrm{pg} / \mathrm{ml}$ inhibin $\mathrm{A} ; 15.6 \mathrm{pg} / \mathrm{ml}$ inhibin $\mathrm{B}$ ) and precise. The intraassay variation was $5 \cdot 71 \%$ and $5 \cdot 69 \%$ for inhibin $A$ and inhibin $\mathrm{B}$ assays respectively. The interassay variation was $23 \cdot 2 \%$ and $24 \cdot 1 \%$ for inhibin A and inhibin B assays respectively. The activin A standard was bovine follicular fluid and the limit of detection of this assay was $5 \mathrm{ng} / \mathrm{ml}$.

\section{Protein extraction and Western blot analysis}

Protein was extracted from whole ovaries by grinding the tissue on dry ice with a mortar and pestle. The tissue was collected in protein extraction buffer $(10 \mathrm{mM}$ Tris, $0.5 \mathrm{M}$ $\mathrm{NaCl}, 1 \mathrm{mM} \mathrm{MgCl}, 0 \cdot 1 \%$ Triton $\mathrm{X}-100$, and protease inhibitors (Complete mini protease inhibitor cocktail tablets, Roche Laboratories, Indianapolis, IN, USA). Protein samples were electrophoresed under reducing or nonreducing conditions in NuPage Bis-Tris $4-12 \%$ gradient gels (Novex, Invitrogen Corp., Carlsbad, CA, USA). Samples were incubated in NuPage LPS sample buffer at $70{ }^{\circ} \mathrm{C}$ for $10 \mathrm{~min}$ before loading. The gels were run in MES-SDS Running Buffer and NuPage Reducing Agent using the NuPage mini gel apparatus. Proteins were transferred to Protran nitrocellulose (Schleicher \& Schwell, Keene, NH, USA). The recombinant human inhibin standards used were rh-inhibin A and rh-inhibin B (R\&D Systems Inc., Minneapolis, MN, USA), and the recombinant human activin standards used were rh-activin $\mathrm{A}$ and rh-activin $\mathrm{B}$ produced in our laboratory by Magdalena Suszko. The blots were blocked in 10\% milk, $1 \times$ Tris-buffered saline (TBS) and $0 \cdot 1 \%$ Tween 20 for $1 \mathrm{~h}$ at room temperature. The blots were incubated with $0 \cdot 15 \mu \mathrm{g} / \mathrm{ml}$ primary antibodies in 5\% milk, $1 \times \mathrm{TBS}, 0 \cdot 1 \%$
Tween for $1 \mathrm{~h}$. The antibodies used (rabbit anti $\alpha$ (305-214-ET, amino acids 1-26 GY), $\beta_{\mathrm{A}^{-}}(305-24-\mathrm{D}$, amino acids 81-113) or $\beta_{\mathrm{B}}$ (305-25-D, amino acids 80-112)-subunit polyclonal antibodies (Shaha et al. 1989, Jin et al. 2001)) were kindly provided by Wylie Vale (Salk Institute, La Jolla, CA, USA). The blots were washed three times for $15 \mathrm{~min}$ in $1 \times$ TBS and $0.1 \%$ Tween and incubated with a 1:10000 dilution of horseradish peroxidase conjugated donkey anti-rabbit secondary antibody (Amersham Pharmacia Biotech Inc., Piscataway, NJ, USA) in 5\% milk, $1 \times$ TBS and $0 \cdot 1 \%$ Tween for $30 \mathrm{~min}$. The blots were washed three times for $15 \mathrm{~min}$ in $1 \times$ TBS and $0 \cdot 1 \%$ Tween. The immunoblots were analyzed by ECL development (Amersham Pharmacia Biotech, Inc.). The immunoblots were exposed to x-ray film for 1 to $120 \mathrm{~min}$

\section{Statistical analyses}

Values are reported as the means \pm S.E. Correlations between ligands were determined using simple linear regression analyses. In all cases, $P<0 \cdot 05$ was considered significant. Paired comparisons were made using paired $t$-test.

\section{Results}

RT-PCR amplification, cloning, and sequencing of the Siberian hamster inhibin $\alpha$-subunit cDNAs

The full-length Siberian hamster inhibin $\alpha$-subunit cDNA was cloned by a combination of library screening, RTPCR, and 5'-RACE (GenBank accession number AF432351). The cDNA was determined to contain an open reading frame (ORF) of $1098 \mathrm{bp}$, flanked by $61 \mathrm{bp}$ and $210 \mathrm{bp}$ of $5^{\prime}$ - and $3^{\prime}$-untranslated regions (UTRs). The ORF is predicted to encode a protein of 366 amino acids, identical in length to the rat and mouse $\alpha$-subunits (Fig. 1; Woodruff et al. 1987, Albano et al. 1993). There is an in-frame stop codon 6 bp upstream of the first ATG in 5 '-UTR and a consensus polyadenylation signal $22 \mathrm{bp}$ upstream of the poly A tail in the $3^{\prime}-\mathrm{UTR}$. The sequence encoding the mature region of the hamster $\alpha$-subunit nucleotide sequence was $91 \%, 90 \%$ and $82 \%$ identical to the mature subunit of the mouse, rat and human respectively. The precursor predicted amino acid sequence was $92 \%, 92 \%$ and $82 \%$ identical to the mouse, rat and human predicted precursor sequences respectively. The Siberian hamster protein sequence encoding the mature region of the inhibin $\alpha$-subunit conservation is fairly high, sharing $96 \%, 96 \%$, and $84 \%$ identity to mouse, rat, and human respectively (Mason et al. 1986, Woodruff et al. 1987, Albano et al. 1993). A dibasic Arg-Arg proteolytic cleavage site at amino acids 232 and 233 is preserved in the hamster protein, suggesting that the mature inhibin $\alpha$-subunit will include the $\alpha$ C-terminal 133 amino acids. 


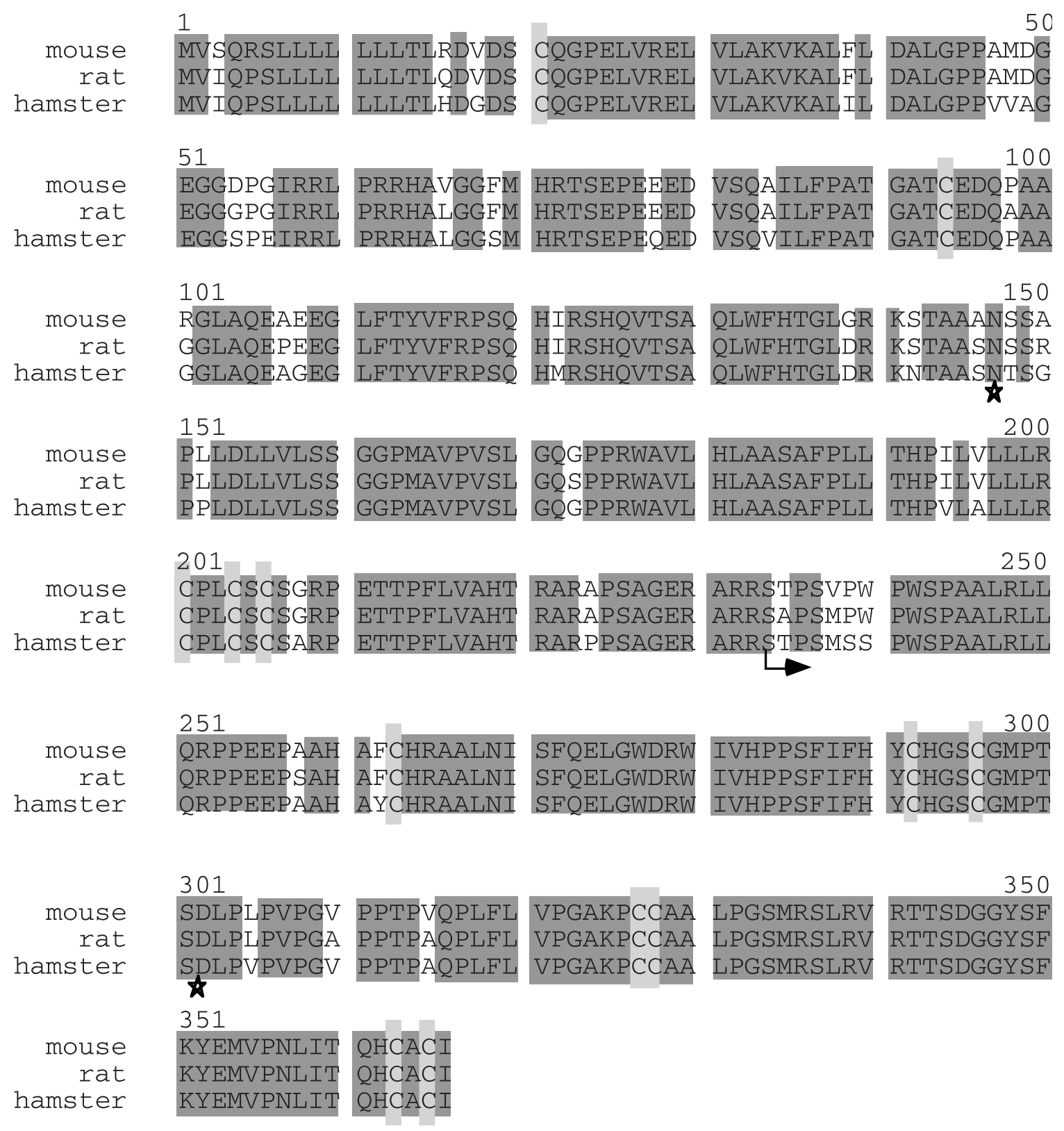

Figure 1 Amino acid sequence alignment for mouse (GenBank accession no. X69618), rat (GenBank accession no.

NP036722) and Siberian hamster (GenBank accession no. AF432351) inhibin $\alpha$-subunit. Conserved amino acids are darkly shaded and conserved cysteine residues are lightly shaded. The start of the mature region of the $\alpha$-subunit is indicated by an arrow and the mature $\alpha$-subunit is 133 amino acids in length. The $\mathrm{N}$-glycosylation sites (stars) are at amino acids 147 and 302 , as previously described in rat and mouse (Mason et al. 1996).

In addition, seven cysteines and a single predicted glycosylation site are conserved between rat, mouse, and Siberian hamster mature proteins. A notable difference between human and rodent mature $(\alpha \mathrm{C}) \alpha$-subunit is that human $\alpha \mathrm{C}$ may be glycosylated at one or two N-linked sites (Mason et al. 1996).
Partial precursor and mature regions of the inhibin $\beta_{\mathrm{A}^{-}}$ and $\beta_{\mathrm{B}}$-subunits were amplified by RT-PCR and ligated into plasmids. The nucleotide sequences for the regions amplified for the $\beta_{\mathrm{A}}$-subunit and the $\beta_{\mathrm{B}}$-subunit cDNAs were $95 \%$ and $92 \%$ identical to rat and mouse $\beta_{\mathrm{A}^{-}}$and $\beta_{\mathrm{B}}$-subunit sequences respectively. 


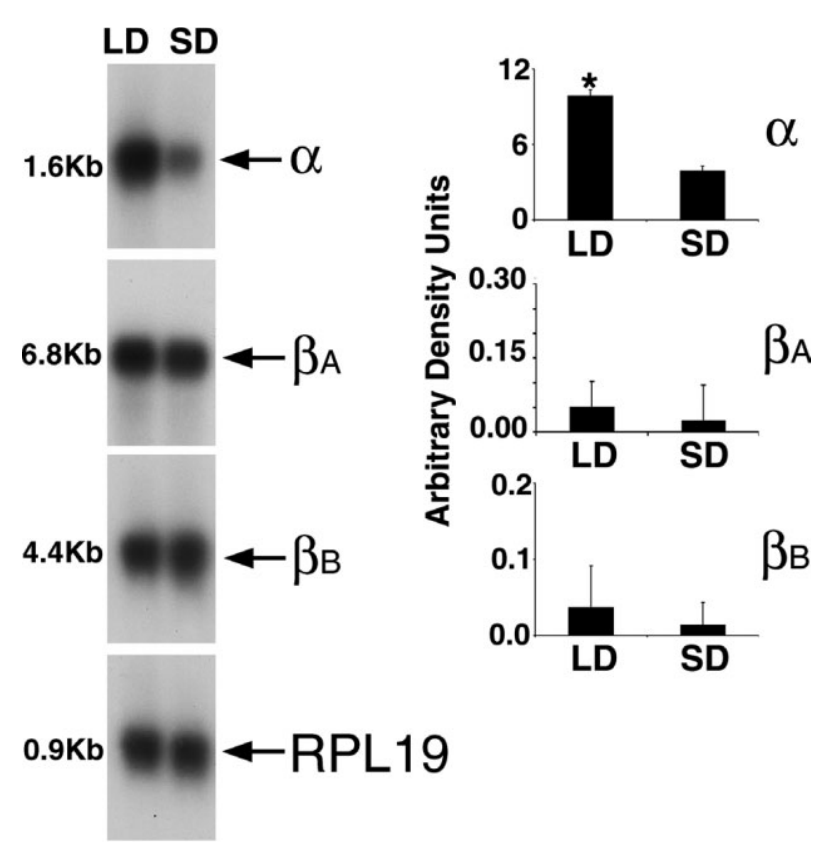

Figure 2 Analysis of inhibin $\alpha-, \beta_{\mathrm{A}^{-}}$and $\beta_{\mathrm{B}}$-subunit mRNA levels in ovaries of long day-exposed (LD) and short day-exposed (SD) hamsters. RNA $(20 \mu \mathrm{g})$ was electrophoresed and transferred to Hybond $\mathrm{N}$ nylon membrane. The blot was hybridized to $\alpha-, \beta_{\mathrm{A}^{-}}$ and $\beta_{\mathrm{B}}$-specific probes, exposed to a Phosphor screen and analyzed as described in Materials and Methods. The relative $\alpha$-subunit mRNA intensity level was significantly higher in the ovaries of LD than of SD hamsters $\left({ }^{*} P<0 \cdot 001\right)$. There was no significant difference in $\beta_{\mathrm{A}^{-}}$or $\beta_{\mathrm{B}}$-subunit mRNA levels in ovaries of LD or SD hamsters. RPL19 was used as a loading control. These results are representative of the results of three independent experiments ( $n=12$ per photoperiodic condition).

\section{Abundance of inhibin subunits in ovaries collected from hamsters reared in long and short photoperiods}

Female hamsters were weaned at 20 days of age and immediately housed in an LD or SD photoperiod for $4-5$ weeks. Relative levels of inhibin $\alpha_{-}, \beta_{\mathrm{A}^{-}}$and $\beta_{\mathrm{B}^{-}}$-subunit mRNAs were measured by RNA blot analysis (Fig. 2). Inhibin $\alpha$-subunit mRNA levels were significantly higher in LD than in SD animals. No significant difference was detected in the abundance of the $\beta_{\mathrm{A}^{-}}$or $\beta_{\mathrm{B}}$-subunit mRNA levels when total ovarian RNA was compared between LD and SD animals. The abundance of the inhibin $\alpha$-subunit was greater than both $\beta_{\mathrm{A}^{-}}$and $\beta_{\mathrm{B}^{-}}$ subunits at all times.

\section{Inhibin subunit $m R N A$ compartmentalization in long and short photoperiod hamster ovaries}

The total abundance of the inhibin $\alpha$-subunit mRNA differed between ovaries collected from LD and SD hamsters. To study the pattern of inhibin subunit expression as it relates to follicle dynamics, hamsters were weaned and immediately housed in an LD or an SD photoperiod for 4-5 weeks. The animals were not cyclic, as determined by the lack of vaginal opening in all animals studied. The ovaries contralateral to those used for determination of the overall abundance of the subunit mRNAs were prepared for in situ hybridization using subunit-specific riboprobes as previously described (Woodruff et al. 1987). Follicles of all size classes up to $520 \mu \mathrm{m}$ were detected in the ovaries from LD animals (Fig. 3A-F), while few follicles reached $400 \mu \mathrm{m}$ in the SD animals (Fig. $3 \mathrm{G}-\mathrm{L}$ ). On average, fewer follicles were positive for the inhibin $\alpha$-subunit in the SD ovaries when compared with the LD follicles (compare Fig. 3A with $3 \mathrm{G}$ ). In addition, the overall level of inhibin $\alpha$-subunit expression was lower in SD, size-matched follicles (compare Fig. 3D with 3J). Thus few follicles expressed the inhibin $\alpha$-subunit in SD ovaries, and the level of inhibin $\alpha$-subunit expression was lower than in LD ovaries. No corpora lutea were detected in any animal regardless of housing conditions.

Both $\beta_{\mathrm{A}^{-}}$and $\beta_{\mathrm{B}}$-subunits were detected in a subset of follicles positive for the $\alpha$-subunit. In general, the expression of $\beta$-subunits overlapped with each other and with the $\alpha$-subunit. In some follicles, the $\beta_{\mathrm{B}}$-subunit was preferentially expressed in the antral granulosa cells while the $\beta_{\mathrm{A}}$-subunit was found throughout the mural and antral granulosa cell layers (see arrows, Fig. 3E and F).

\section{Regulation of inhibin subunit synthesis and processing in ovaries from long and short photoperiod Siberian hamsters}

Serum was collected from LD and SD hamsters and FSH, $\mathrm{LH}$, inhibin $\mathrm{A}$, inhibin $\mathrm{B}$, and total activin $\mathrm{A}$ were measured (Table 2). The serum levels of inhibin $A$ and inhibin B were low to undetectable $(<7.8 \mathrm{pg} / \mathrm{ml})$ in both LD and SD animals using currently available assays. Sporadic, low levels of inhibin A were detected in both LD and SD animals, but not consistently. The inhibin A and inhibin B assays were validated for hamster serum using pregnant mare serum gonadotropin-induced serum samples (see the companion paper Kenny et al. 2002). The levels of activin A were also undetectable $(<5 \mathrm{ng} / \mathrm{ml})$ in both LD and SD hamster serum. FSH levels were significantly higher in LD hamsters than in SD hamsters. There was no statistically significant photoperiodic difference in the serum levels of LH.

Because the component subunit mRNAs were detected in the ovary yet no circulating inhibin or activin could be measured, we examined the abundance of dimeric inhibin or the three subunits by protein blot analysis. In the ovary, two dominant precursor species of dimeric inhibin were detected. A high molecular weight form (approximately 80-90 kDa) was detected (Fig. 4A, black arrowhead). In ovarian homogenates from LD females, two precursor forms were detected between 80 and $90 \mathrm{kDa}$, likely 

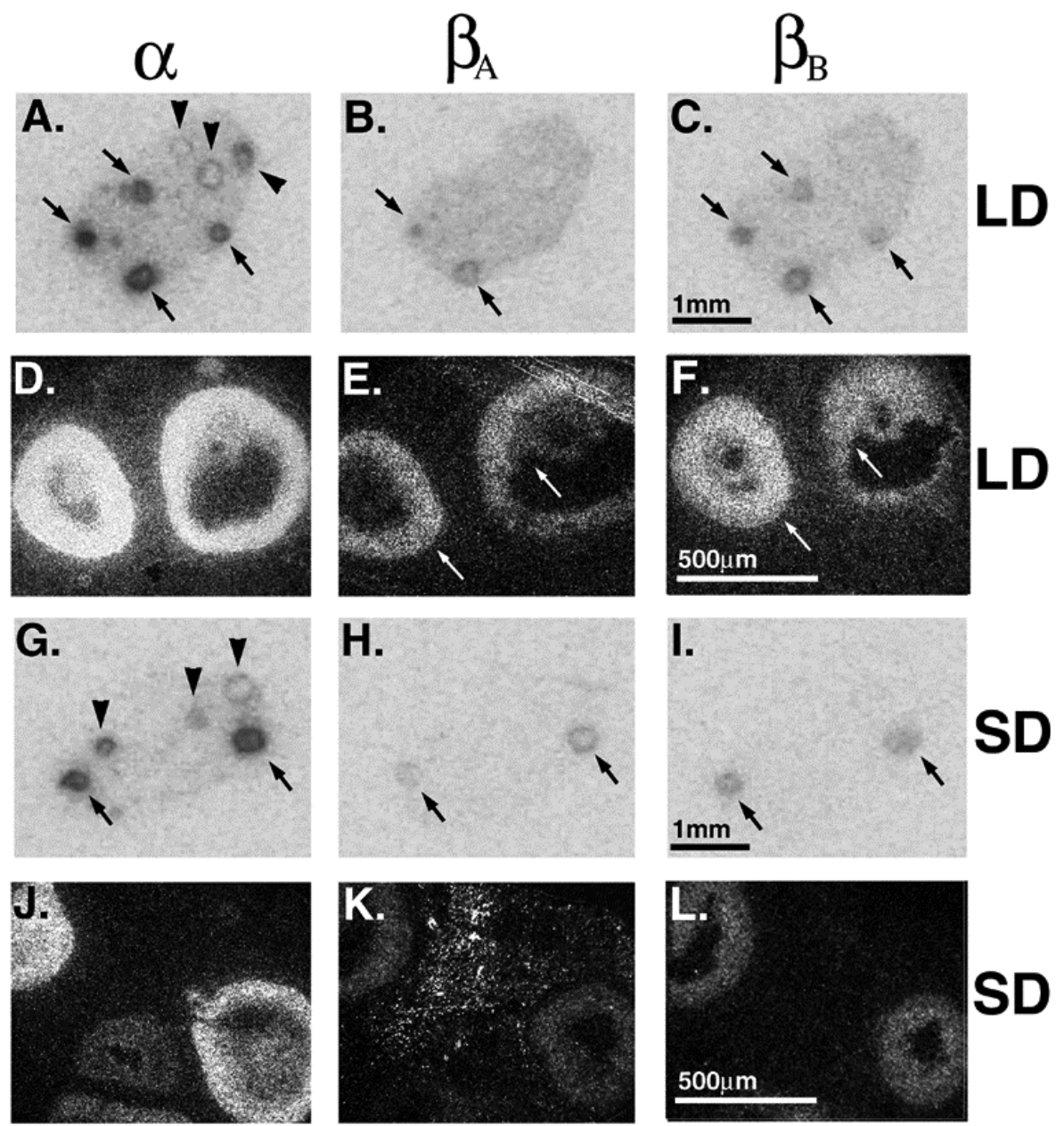

Figure 3 In situ hybridization of inhibin $\alpha_{-}, \beta_{\mathrm{A}^{-}}$and $\beta_{\mathrm{B}^{-}}$-subunit mRNA in ovaries of LD and SD hamsters. CRNA probes for the $\alpha_{-}, \beta_{A^{-}}$and $\beta_{B}$-subunits were produced and hybridized to ovarian tissue sections as described in Materials and Methods. (A-C) $\alpha-, \beta_{A^{-}}$and $\beta_{B}$-subunit mRNA expression in cross sections of the entire ovary of LD hamsters were analyzed on x-ray film. Both $\beta_{A^{-}}$and $\beta_{B}$-subunits were detected in a subset of follicles positive for the $\alpha$-subunit (arrows; $A-C$ ). Some follicles expressed only the $\alpha$-subunit (arrow heads; A). A scale bar is located in panel $\mathrm{C}$ for panels A-C. (D-F) $\alpha-, \beta_{A^{-}}$and $\beta_{B}$-subunit mRNA expression is shown in antral (left follicle) and Graafian (right follicle) follicles in adjacent ovarian sections of LD hamsters. The localization of $\beta_{A^{-}}$ and $\beta_{\mathrm{B}}$-subunit expression in mural (left arrow; $\mathrm{E}$ and $\mathrm{F}$ ) and cumulus (right arrow; $\mathrm{E}$ and $\mathrm{F}$ ) granulosa cells is illustrated. A scale bar is located in panel $F$ for panels $D-F$. (G-I) $\alpha_{--}, \beta_{A^{-}}$and $\beta_{B}$-subunit expression in cross sections of the entire ovary of SD hamsters were analyzed on x-ray film. Both $\beta_{\mathrm{A}^{-}}$and $\beta_{\mathrm{B}^{-}}$-subunits were detected in a subset of follicles positive for the $\alpha$-subunit (arrows; G-I). Some follicles expressed only the $\alpha$-subunit (arrow heads; G). A scale bar is located in panel I for panels $\mathrm{G}-\mathrm{I}$. (J-L) $\alpha-, \beta_{\mathrm{A}^{-}}$and $\beta_{\mathrm{B}^{-}}$subunit mRNA expression are shown in the largest antral follicles found in the ovaries of SD hamsters.

representing additional glycosylation, while only one form was detected in the ovarian lysates from SD females. A second precursor (two bands approximately $36-41 \mathrm{kDa}$ ) was detected in ovarian lysates from LD and SD females (Fig. 4A, black arrows). Mature dimeric inhibin was not detected in ovarian lysates from LD or SD females (Fig. $4 \mathrm{~A}$, gray arrows). When samples were reduced to break the disulfide bonds, the mature inhibin $\alpha$-subunit and the precursor $\alpha \mathrm{N} \alpha \mathrm{C}$ subunit were detected in LD ovaries, while no fully processed mature $\alpha$-subunit could be detected in the ovaries from females housed in a short photoperiod (Fig. 4B). Similarly, mature $\beta_{\mathrm{A}^{-}}$and $\beta_{\mathrm{B}^{-}}$ subunits were detected in ovaries of LD females but not of SD females (Fig. 4C and D).

Ovarian inhibin levels were also measured in LD and SD Siberian hamsters (Fig. 5). The levels of inhibin A 
Table 2 Gonadotropin, inhibin A, inhibin B and activin A serum levels and body weights of LD- and SD-exposed hamsters. The circulating levels of FSH, LH, inhibin A, inhibin B and activin, and the body weights are reported as means \pm S.E. The range of values for each measurement is listed in parentheses. LTS refers to values less than the standards used in each assay or lower than the limit of detection of the assay $(<7 \cdot 8 \mathrm{pg} / \mathrm{ml}$ inhibin A; $<15.6 \mathrm{pg} / \mathrm{ml}$ inhibin $\mathrm{B} ;<5 \mathrm{ng} / \mathrm{ml}$ activin A). These results are representative of three independent experiments with more than six animals per treatment

\begin{tabular}{|c|c|c|}
\hline & Long photoperiod (LD) & Short photoperiod (SD) \\
\hline $\mathrm{FSH}(\mathrm{ng} / \mathrm{ml})$ & $8 \cdot 1 \pm 0 \cdot 7(4 \cdot 3-13 \cdot 0)^{*}$ & $4 \cdot 3 \pm 0 \cdot 6(1 \cdot 0-7 \cdot 1)$ \\
\hline $\mathrm{LH}(\mathrm{ng} / \mathrm{ml})$ & $0 \cdot 6 \pm 0 \cdot 2(0 \cdot 2-1 \cdot 7)$ & $0 \cdot 8 \pm 0 \cdot 3(0 \cdot 2-3 \cdot 2)$ \\
\hline Inhibin $\mathrm{A}(\mathrm{pg} / \mathrm{ml})$ & LTS (LTS-82·6) & LTS (LTS-60·8) \\
\hline Inhibin B (pg/ml) & LTS (LTS-47·3) & LTS (LTS-40·8) \\
\hline Activin A (ng/ml) & LTS (LTS) & LTS (LTS) \\
\hline Body weight (g) & $34 \cdot 2 \pm 3 \cdot 4(30-44)$ & $23 \cdot 6 \pm 2 \cdot 3(20-29)$ \\
\hline
\end{tabular}

${ }^{*} P<0 \cdot 05$, LD compared with SD animals.

and inhibin B were higher in the LD than SD hamsters. In the LD hamsters, ovarian inhibin A levels ranged from 6.85 to $38.39 \mathrm{pg} / \mathrm{mg}$ ovary with a mean value of $22.93 \pm 2.63 \mathrm{pg} / \mathrm{mg}$ ovary, and ovarian inhibin B levels ranged from 11.05 to $50.00 \mathrm{pg} / \mathrm{mg}$ ovary with a mean value of $27.59 \pm 3.89 \mathrm{pg} / \mathrm{mg}$ ovary. In the SD hamsters, inhibin A levels were less than the standard range and inhibin $\mathrm{B}$ levels ranged from less than the standard range to $5.81 \mathrm{pg} / \mathrm{mg}$ ovary with a mean value of $3.43 \pm 0.43 \mathrm{pg} /$ mg ovary.

\section{Discussion}

The regulation of reproductive function relies on carefully orchestrated feed-forward and feedback signals produced by the brain, pituitary and gonads. In many species, environmental cues are also used to time reproductive effort such that offspring are born at those times of year most conducive to their survival. For example, the Siberian hamster (Phodopus sungorus) uses seasonal changes in day length to time changes in gonadal size and activity, body weight, and pelage color (Hoffmann 1973, Lerchl \& Schlatt 1993, Ebling 1994). These changes can be recapitulated in laboratory animal breeding colonies by altering daily light exposure. Thus, the Siberian hamster can be used to study the impact of photoperiod on the endogenous hormones that communicate between the brain, pituitary, and testis or ovary. One of the most important endocrine hormones emanating from the ovary to control pituitary function is inhibin. Thus, the intent of this study was to examine the role of inhibin in the regulation of photoperiod-dependent seasonal changes in reproductive function in the Siberian hamster.

Inhibin regulates normal reproductive function in a number of species by inhibiting FSH secretion and it was our prediction that inhibin would also be important to the regulation of reproductive function in the female Siberian hamster. Inhibin subunit expression in the ovaries has been characterized in several other rodent species (Meunier et al. 1988, 1989, Woodruff et al. 1988, Jih et al. 1993, McAsey et al. 1995, O’Shaughnessy \& Gray 1995, Otsuka et al. 1997, Oshima et al. 1999). The hamster inhibin subunits were cloned and used to examine changes in the abundance of each of the subunits in LD or SD animals. Each of the hamster inhibin subunits are highly conserved at the protein level and all of the hallmark glycosylation sites, cysteine motifs and cleavage sites are present in the hamster, just as they are in other rodent species (Woodruff et al. 1987, Albano et al. 1993). In addition, we estimate that $\alpha$-subunit mRNA levels are 10 - to 20 -fold higher in abundance in the hamster ovary than are the $\beta$-subunit mRNAs. Interestingly, $\alpha$-subunit mRNA levels are less than half as great in SD as in LD ovaries. This can be accounted for by the fewer number of follicles expressing the $\alpha$-subunit, the smaller overall size of the follicle pool, and the lower intensity of inhibin $\alpha$-subunit expression in the smaller follicles of the SD ovaries. $\beta$-Subunit expression is restricted to a smaller number of follicles compared with the $\alpha$-subunit in both photoperiods and subtle differences in cellular distribution within the granulosa cell compartment of the follicle is noted. Specifically, the $\beta_{\mathrm{B}}$-subunit is detected in the antral granulosa cell layer of some of the follicles, while no morphological difference could be detected in these follicles when compared with follicles with homogeneous expression of the $\beta_{\mathrm{B}}$-subunit.

Conclusions have often been drawn regarding inhibin secretion based on inhibin expression. In this study, we measured inhibin A and B serum levels in order to investigate the correlation between subunit expression and circulating inhibin levels. Surprisingly, little or no inhibin was detected in serum samples collected from animals housed under long or short photoperiods. It is possible that inhibin is secreted but at a level that is too low to detect using the current inhibin ELISAs or that the current inhibin ELISAs are insufficiently sensitive to detect 

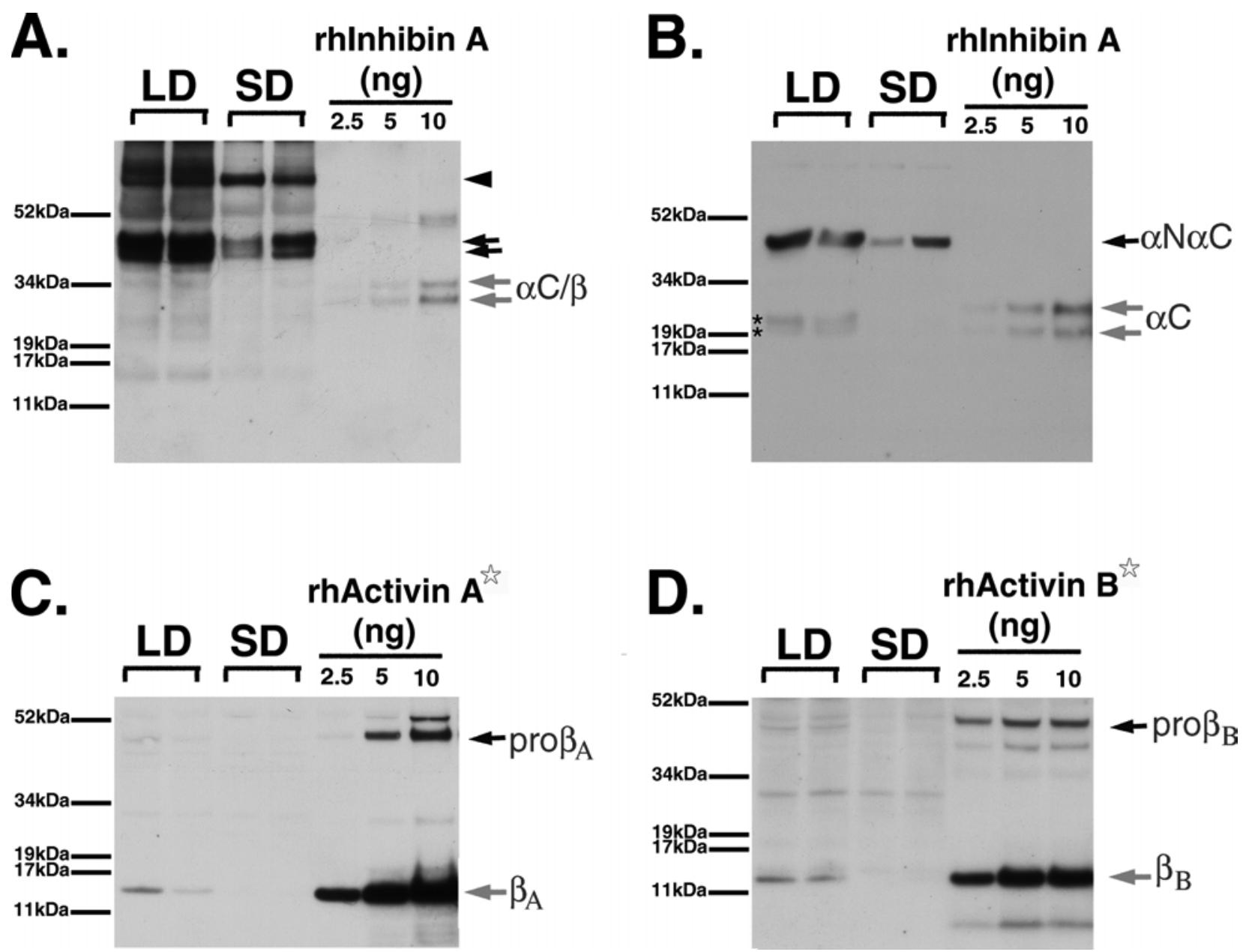

Figure 4 Western blot analysis of inhibin and inhibin $\alpha_{-}, \beta_{\mathrm{A}^{-}}$and $\beta_{\mathrm{B}^{-}}$-subunits in ovarian lysates from LD and SD hamsters. Proteins were extracted from individual ovaries and $40 \mu$ g protein were loaded in each well, as described in Materials and Methods. (A) Immunoblot analysis of ovarian extracts under nonreducing conditions using the $\alpha$-subunit polyclonal antibody. Inhibin was detected as two dominant precursor proteins in ovaries of LD and SD hamsters (black arrowhead and black arrows). The standard, rh-inhibin A, was detected as a mature dimer $(\alpha \mathrm{C} / \beta)$ and precursor proteins. (B) Immunoblot analysis of ovarian extracts under reducing conditions using the $\alpha$-subunit polyclonal antibody. Two mature forms ( $\alpha \mathrm{C}$, asterisks) and precursor forms $(\alpha \mathrm{N} \alpha \mathrm{C})$ of the $\alpha$-subunit were detected. The standard, rh-inhibin $\mathrm{A}$, was detected in its nonglycosylated and diglycosylated mature $\alpha$-subunit form $(\alpha \mathrm{C})$. (C) Immunoblot analysis of ovarian extracts under reducing conditions using the $\beta_{A^{-}}$subunit polyclonal antibody. The mature $\beta_{A^{-}}$subunit $\left(\beta_{\mathrm{A}}\right)$ was detected in the ovary of LD hamsters. The standard, rh-activin A conditioned media, was detected as mature and precursor proteins (pro $\beta_{A}$ ) of the inhibin $\beta_{A}$-subunit (gray star). (D) Immunoblot analysis of ovarian extracts under reducing conditions using the $\beta_{\mathrm{B}}$-subunit polyclonal antibody. The mature $\beta_{B}$-subunit $\left(\beta_{B}\right)$ and precursor proteins $\left(\right.$ pro $\left.\beta_{B}\right)$ were only detected in the ovaries of LD hamsters. The standard, rh-activin B conditioned media, was detected as mature and precursor proteins of the inhibin $\beta_{\mathrm{B}}$-subunit (gray star).

inhibin in the hamster. The current inhibin ELISAs use monoclonal antibodies against amino acids $1-32$ of the human $\alpha \mathrm{C}$ region of the $\alpha$-subunit (Groome et al. 1990). A comparison of the 1-32 amino acid sequence of the human and Siberian hamster mature $\alpha$-subunit reveals that there are four different amino acids which may lead to a reduced immunoactivity in the inhibin $\mathrm{A}$ and inhibin $\mathrm{B}$ ELISAs. The current inhibin ELISAs do not detect bovine or mouse inhibin A and inhibin B. A comparison of the structure of the $\mathrm{N}$-terminal region of the mature $\alpha$-subunit between hamster (GenBank accession no. AF432351) and human (GenBank accession no. BC006391) revealed differences at amino acids 4, 7, 12 and 28, while a comparison between bovine (GenBank accession no. A25732) and human (GenBank accession no. BC006391) and between mouse (GenBank accession no. X69618) and human (GenBank accession no. BC006391) both revealed differences at amino acids 4-6, 12 and 28. In a companion paper, we demonstrate that inhibin A and inhibin B can be detected in the serum in response to exogenous gonadotropins, so we have confirmed that the ELISAs used can detect inhibin A and B in Siberian hamsters (Kenny et al. 


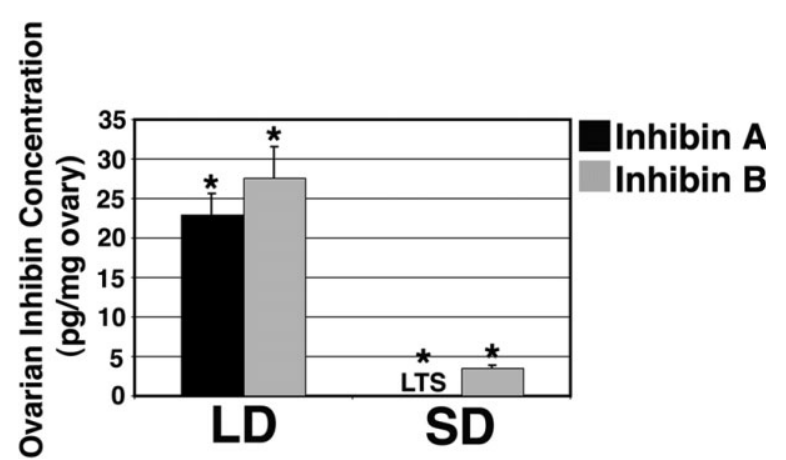

Figure 5 Measurement of ovarian inhibin A and inhibin B content by ELISA. LTS refers to values less than standards used in each assay or lower than the limit of detection of the assay $(<7 \cdot 8 \mathrm{pg} / \mathrm{ml}$ inhibin $A ;<15.6 \mathrm{pg} / \mathrm{ml}$ inhibin $\mathrm{B}$ ). There was a significant difference in levels of inhibin $A$ and inhibin $B$ between the LD and SD animal groups $\left({ }^{*} P<0 \cdot 05\right)$. These results represent three independent experiments $(n=9)$.

2002). We did detect inhibin A and inhibin B at low levels in a few animals housed under long and short photoperiods (Table 2), suggesting that some inhibin is being secreted sporadically but not in sufficient quantity to be detected in the assay. When ovarian homogenates were measured in the assay, dimeric inhibin A and inhibin B were detected in the LD but no inhibin A and significantly lower levels of inhibin B were detected in the SD samples. By Western blot analysis, little mature inhibin was detected in the SD samples. We hypothesize that the low circulating levels of inhibin A and inhibin B likely reflect a low rate of mature inhibin synthesis and secretion, but the current inhibin ELISAs may not be sufficiently sensitive to Siberian hamster inhibin to draw this conclusion. The development of a Siberian hamster-specific assay using recombinant hamster inhibins as the standards would resolve this issue.

FSH is known to regulate inhibin synthesis and secretion (Woodruff et al. 1987, 1996). Serum FSH levels did differ between the two populations of animals with no associated difference in LH levels. Thus, while the animals were clearly responsive to the different photoperiods, the levels of FSH in the LD animals appear to have been insufficient to promote cyclicity. It is possible that additional environmental cues are necessary to promote full reproductive function in this species (Goldman 1991, Ouarour et al. 1991, Puchalski \& Lynch 1991, Badura \& Goldman 1992, Debeljuk \& Lasaga 1999, Drazen et al. 2001, Horton \& Yellon 2001, Pak et al. 2001). The LD animals used were 7 weeks old and, based on previous studies, were thought to be sexually mature (Lerchl \& Schlatt 1993, Schlatt et al. 1993). However, no vaginal opening was detected, thus contributing to our conclusion that the animals were not cycling. The animals in this study were individually housed in an environment free of male pheromones. Thus, cyclicity was solely dependent on light and endogenous hormones.
Because FSH levels differed between LD and SD animals yet serum inhibin levels were not adequately detected in the current assay, we examined inhibin synthesis and assembly in ovarian homogenates by protein blot analysis. The advantage of this method is that mature and precursor forms of the proteins can be detected to allow a more complete understanding of the synthesis and assembly of inhibin before it is secreted. Few studies have investigated the synthesis of inhibin subunits by the normal ovary, and there is a dirth of understanding regarding the regulation of inhibin translation and posttranslational modification in any animal model (Findlay et al. 2001, Pangas \& Woodruff 2001). Much of our knowledge regarding inhibin synthesis is derived from the products of recombinant cell lines (Pangas \& Woodruff 2001). Thus, this analysis represents the first comprehensive investigation of naturally occurring inhibin subunit production. Inhibin proteins are produced by the hamster ovaries and the predominant forms detected in the LD and SD animals are precursors, the mature $\beta$-subunit $(\beta)$ disulfide linked to the precursor $\alpha$-subunits, $\alpha \mathrm{N} \alpha \mathrm{C}$ or pro- $\alpha \mathrm{C}$. The abundance of these precursor proteins is higher in LD than in SD animals. No mature inhibins $(\alpha \mathrm{C} / \beta)$ are detected in the LD or SD ovarian lysates. When the protein is reduced, the pro- $\alpha \mathrm{C} / \beta$ band is lost because the disulfide bonds joining the pro-region of the $\alpha$-subunit to the mature domain of the $\alpha$-subunit and the bond linking the mature $\alpha$-subunit to the mature $\beta$-subunit are broken. As a result, the higher molecular weight dimer is reduced and the mature $\alpha$-subunit $(18 \mathrm{kDa})$ and mature $\beta$-subunits $(14 \mathrm{kDa}$ and $13 \mathrm{kDa}$ for $\beta_{\mathrm{A}^{-}}$and $\beta_{\mathrm{B}^{-}}$-respectively) are detected. The antibody used in this analysis recognizes amino acids $1-32$ of the mature $\alpha$-subunit, thus, a band representing the precursor protein is not detected under reducing conditions. By contrast, little mature $\alpha$-subunit is detected in the SD animals, even under reducing conditions. This observation is consistent with the differences observed in $\alpha$-subunit mRNA levels.

Similarly, $\beta_{\mathrm{A}^{-}}$and $\beta_{\mathrm{B}^{-}}$subunits are both detected in ovarian lysates of LD females but not of SD females. This result is somewhat surprising given the equivalent $\beta_{\mathrm{A}}$ and $\beta_{\mathrm{B}}$ mRNA levels detected in the ovaries collected from animals under the two photoperiods. While a direct comparison between the abundance of the inhibin $\alpha$-subunit and the two $\beta$-subunits cannot be carried out due to differences in antibodies, it is likely that the $\alpha$-subunit is in sufficient abundance relative to the $\beta$-subunits to produce inhibin in excess of activin. Consistent with this argument, although not definitive, is our inability to detect activin in serum samples collected from these animals.

Although LD animals were not cycling (based on a lack of vaginal opening), follicles were developing through the large antral follicle stage and inhibin subunits were detected in the granulosa cells of these developing follicles. No evidence of previous ovulation was detected, based on 
the absence of corpora lutea. In addition, serum FSH but not LH was significantly higher in LD compared with SD animals. Likely as a consequence of these FSH levels, inhibin $\alpha$-subunit expression was higher within given follicles and was expressed in a larger number of follicles in LD animals. Higher levels of inhibin precursors were detected in ovarian homogenates of long photoperiod than short photoperiod animals. This final finding was not anticipated. Little is known regarding the processing of inhibin by any cell including the recombinant inhibin cell lines. The dibasic arginines are important for cleavage, but it is not known what protease is responsible for this regulation. These data suggest that some processing has occurred but the disulfide bond linking the precursor domain to the mature domain of the inhibin $\alpha$-subunit is intact. Thus, a processing enzyme such as a disulfide isomerase may be regulated and contribute to inhibin production in heretofore unappreciated ways. The identification of the proteases and isomerases necessary for inhibin processing will be key to our understanding of the regulation of the normal reproductive cycle. In addition, we detected little inhibin secretion in the animals studied. This may reflect limited secretion of precursor inhibin subunits into the systemic circulation of LD and SD animals or that the current inhibin ELISAs are not sensitive enough to measure circulating inhibin in this animal model.

In conclusion, both serum FSH and ovarian inhibin A and inhibin B levels are higher in LD than in SD animals. Serum inhibin levels do not differ conclusively between the photoperiods. These data suggest that inhibin does not significantly contribute to the seasonal differences in FSH (at least not in non-cycling LD females). In contrast, there is significant inhibin A and inhibin B production within the ovaries and the amount produced differs between photoperiods. $\alpha$-Subunit mRNA is higher in LD than in $\mathrm{SD}$ animals, as is $\alpha$-subunit protein forms. $\beta$-Subunit mRNAs do not differ between the photoperiods but subunit protein synthesis appears to be higher in the LD than in the SD animals. These studies raise significant new questions regarding our understanding of the transcriptional, translational, post-translational modification, and secretion of inhibin by the ovary. The advantage of the Siberian hamster system is that subtle changes in follicular status can apparently be investigated with minimal changes in circulating gonadotropins. Based on these studies, the response of the inhibin system to high levels of gonadotropins was investigated in order to evaluate whether local or non-gonadotropin factors are involved in each of these steps in inhibin secretion (see the companion paper Kenny et al. 2002). The results of these studies are significant in that they change our understanding of the link between transcription and the subsequent processes needed to release a bioactive inhibin molecule. Future studies will focus on whether these steps in inhibin biosynthesis are regulated in other animal models such as the rat and the human.

\section{Acknowledgements}

The authors wish to thank W Vale who provided the inhibin subunit antibodies, B Mann who conducted the gonadotropin RIAs, M Suszko who provided the rh-activin A and rh-activin B conditioned media, and $\mathrm{S}$ Pangas who provided the purified rh-inhibin $\mathrm{A}$ and rh-inhibin B. This study was supported by NIH grants HD-21921, HD-37096 and HD-28048 to T K Woodruff. $\mathrm{H}$ A Kenny is a Fellow of the Training Program in Reproductive Biology (HD00768). D J Bernard is a Lalor Foundation Postdoctoral Fellow.

\section{References}

Albano RM, Groome N \& Smith JC 1993 Activins are expressed in preimplantation mouse embryos and in ES and EC cells and are regulated on their differentiation. Development 117 711-723.

Badura LL \& Goldman BD 1992 Prolactin-dependent seasonal changes in pelage: role of the pineal gland and dopamine. Journal of Experimental Zoology 261 27-33.

Bernard DJ \& Woodruff TK 2001 Inhibin binding protein in rats: alternative transcripts and regulation in the pituitary across the estrous cycle. Molecular Endocrinology 15 654-667.

Besecke LM, Guendner MJ, Sluss PA, Polak AG, Woodruff TK, Jameson JL, Bauer-Dantoin AC \& Weiss J 1997 Pituitary follistatin regulates activin-mediated production of follicle-stimulating hormone during the rat estrous cycle. Endocrinology 138 2841-2848.

Debeljuk L \& Lasaga M 1999 Modulation of the hypothalamopituitary-gonadal axis and the pineal gland by neurokinin A, neuropeptide K and neuropeptide gamma. Peptides 20 285-299.

Drazen, DL, Demas GE \& Nelson RJ 2001 Leptin effects on immune function and energy balance are photoperiod dependent in Siberian hamsters (Phodopus sungorus). Endocrinology 142 2768-2775.

Ebling FJ 1994 Photoperiodic differences during development in the dwarf hamsters Phodopus sungorus and Phodopus campbelli. General and Comparative Endocrinology 95 475-482.

Findlay JK, Drummond AE, Dyson M, Baillie AJ, Robertson DM \& Ethier J 2001 Production and actions of inhibin and activin during folliculogenesis in the rat. Molecular and Cellular Endocrinology 180 139-144.

Goldman BD 1991 Parameters of the circadian rhythm of pineal melatonin secretion affecting reproductive responses in Siberian hamsters. Steroids 56 218-225.

Groome M \& Lawrence M 1991 Preparation of monoclonal antibodies reacting with beta-A subunit of human ovarian inhibin. Hybridoma 10 309-316.

Groome N, Hancock J, Betteridge A, Lawrence M \& Craven R 1990 Monoclonal and polyclonal antibodies reactive with the 1-32 amino terminal sequence of the alpha subunit of human $32 \mathrm{~K}$ inhibin. Hybridoma 9 31-42.

Groome M, Illingworth P \& O’Brien M 1994 Detection of dimeric inhibin throughout the human menstrual cycle by two-site enzyme immunoassay. Clinical Endocrinology 40 717-723.

Groome M, Illingworth P, O’Brien M, Pai R, Rodger F, Mather J \& McNeilly A 1996 Measurement of dimeric inhibin B throughout the human menstrual cycle. Journal of Clinical Endocrinology and Metabolism 81 1401-1405.

Halvorson LM, Weiss J, Bauer-Dantoin AC \& Jameson JL 1994 Dynamic regulation of pituitary follistatin messenger ribonucleic acids during the rat estrous cycle. Endocrinology 134 1247-1253.

Herath CB, Yamashita M, Watanabe G, Jin W, Tangtrongsup S, Kojima A, Groome NP, Suzuki A \& Taya K 2001 Regulation of 
follicle-stimulating hormone secretion by estradiol and dimeric inhibins in the infantile female rat. Biology of Reproduction $\mathbf{6 5}$ 1623-1633.

Hoffmann K 1973 The influence of photoperiod and melatonin on testis size, body weight and pelage color in the Djungarian hamster, Phodopus sungorus. Journal of Comparative Physiology $\mathbf{8 5}$ 267-282.

Horton TH \& Yellon SM 2001 Aging, reproduction, and the melatonin rhythm in the Siberian hamster. Journal of Biological Rhythms 16 243-253.

Hsueh A, Dahl KD, Vaughn J, Tucker E, Rivier J, Bardin CW \& Vale W 1987 Heterodimers and homodimers of inhibin subunits have different paracrine action in the modulation of luteinizing hormone-stimulated androgen biosynthesis. PNAS 84 5082-5086.

Jih MH, Lu JK, Wan YJ \& Wu TC 1993 Inhibin subunit gene expression and distribution in the ovaries of immature, young adult, middle-aged, and old female rats. Endocrinology 132 319-326.

Jin W, Wada S, Arai KY, Kishi H, Herath CB, Watanabe G, Suzuki AK, Groome NP \& Taya K 2001 Testicular secretion of inhibin in the male golden hamster (Mesocricetus auratus). Journal of Andrology 22 207-211.

Kenny HA, Bernard DJ, Horton TH \& Woodruff TK 2002 Photoperiod-dependent regulation of inhibin in Siberian hamsters: II. Regulation of inhibin production and secretion by pregnant mare serum gonadotropin. Journal of Endocrinology 174 85-94.

Knight PG, Muttukrishna S \& Groome NP 1996 Development and application of a two-site enzyme immunoassay for the determination of 'total' activin A concentrations in serum and follicular fluid. Journal of Endocrinology 148 267-279.

Lerchl A \& Schlatt S 1993 Influence of photoperiod on pineal melatonin synthesis, fur, color, body weight, and reproductive function in the female Djungarian hamster, Phodopus sungorus. Neuroendocrinology 57 359-364.

Ling N, Ying SY, Ueno N, Shimasaki S, Esch F, Hotta M \& Guilemin R 1986a A homodimer of the beta-subunits of inhibin A stimulates the secretion of pituitary follicle stimulating hormone. Biochemical and Biophysical Research Communications 138 1129-1137.

Ling N, Ying SY, Ueno N, Shimasaki S, Esch F, Hotta M \& Guillemin R $1986 b$ Pituitary FSH is released by a heterodimer of the beta-subunits from the two forms of inhibin. Nature $\mathbf{3 2 1}$ 779-782.

McAsey ME, Machen N \& Benson B 1995 Immunoreactive inhibin decreases following bilateral ovariectomy and during postovulatory rise of FSH in Syrian hamsters. Life Sciences 57 2057-2071.

Mason AJ, Niall H D \& Seeburg P H 1986 Structure of two human ovarian inhibins. Biochemical and Biophysical Research Communications 135 957-964.

Mason AJ, Farnworth PG \& Sullivan J 1996 Characterization and determination of the biological activities of noncleavable high molecular weight forms of inhibin A and activin A. Molecular Endocrinology 12 1055-1065.

Meunier H, Cajander SB, Roberts VJ, Rivier C, Sawchenko PE, Hsueh AJ \& Vale W 1988 Rapid changes in the expression of inhibin alpha-, beta A-, and beta B-subunits in ovarian cell types during the rat estrous cycle. Molecular Endocrinology 2 1352-1363.

Meunier H, Roberts V J, Sawchenko PE, Cajander SB, Hsueh AJ \& Vale W 1989 Periovulatory changes in the expression of inhibin alpha-, beta A-, and beta B-subunits in hormonally induced immature female rats. Molecular Endocrinology 3 2062-2069.

Muttukrishna S, Fowler PA, George L, Groome NP \& Knight PG 1996 Changes in peripheral serum levels of total activin-A during the human menstrual cycle and pregnancy. Journal of Clinical Endocrinology and Metabolism 81 3328-3334.

O’Shaughnessy PJ \& Gray SA 1995 Gonadotropin-dependent and gonadotropin-independent development of inhibin subunit messenger ribonucleic acid level in the mouse ovary. Endocrinology $1362060-2065$.

Oshima K, Kishi H, Itoh M, Watanabe G, Arai K, Uehara K, Groome NP \& Taya K 1999 Secretion of inhibin A, inhibin B and inhibin pro-alphaC during the oestrous cycle of the golden hamster (Mesocricetus auratus). Journal of Endocrinology 162 451-456.

Otsuka M, Kishi H, Arai K, Watanabe G, Taya K \& Greenwald GS 1997 Temporal changes in inhibin, steroid hormones, and steroidogenic enzymes during induced follicular atresia in the hypophysectomized cyclic hamster. Biology of Reproduction $\mathbf{5 6}$ 423-429.

Ouarour A, Kirsch R \& Pévet P 1991 Effects of temperature, steroids and castration on daily torpor in the Djungarian hamster (Phodopus sungorus). Journal of Comparative Physiology A 168 477-481.

Pak TR, Lynch GR \& Tsai PS 2001 Testosterone and estrogen act via different pathways to inhibit puberty in the male Siberian hamster (Phodopus sungorus). Endocrinology 142 3309-3316.

Pangas SP \& Woodruff TK 2001 Production and purification of recombinant human inhibin and activin. Journal of Endocrinology 172 199-210.

Puchalski W \& Lynch GR 1991 Circadian characteristics of Djungarian hamsters: effects of photoperiod pretreatment and artificial selection. American Journal of Physiology 261 R670-R676.

Rivier C, Vale W \& Rivier J 1987 Studies of inhibin family of hormones: a review. Hormone Research 28 104-118.

Robertson DM, Foulds LM, Prisk M \& Hedger MP 1992 Inhibin/activin beta-subunit monomer: isolation and characterization. Endocrinology 130 1680-1687.

Schlatt S, Niklowitz P, Hoffmann K \& Nieschlag E 1993 Influence of short photoperiods on reproductive organs and estrous cycles of normal and pinealectomized female Djungarian hamsters, Phodopus sungorus. Biology of Reproduction 49 243-250.

Schmelzer CH, Burton LE, Tamony CM, Schwall RH, Mason AJ \& Liegeois N 1990 Purification and characterization of recombinant human activin B. Biochimica et Biophysica Acta 1039 135-141.

Shaha C, Morris PL, Chen CL, Vale W \& Bardin CW 1989 Immunostainable inhibin subunits are in multiple types of testicular cells. Endocrinology 125 1941-1950.

Weiss J, Guendner MJ, Halvorson LM \& Jameson L 1995 Transcriptional activation of the follicle-stimulating hormone beta-subunit gene by activin. Endocrinology 136 1885-1891.

Winters SJ, Pohl CR, Adedoyin A \& Marshall GR 1996 Effects of continuous inhibin administration on gonadotropin secretion and subunit gene expression in immature and adult male rats. Biology of Reproduction 55 1377-1382.

Woodruff TK, Meunier H, Jones PBC, Hsueh AWJ \& Mayo KE 1987 Rat inhibin: molecular cloning of $\alpha$ - and $\beta$-subunit complimentary DNAs and expression in the ovary. Molecular Endocrinology 1 561-568.

Woodruff TK, D’Agostino J, Schwartz NB \& Mayo KE 1988 Dynamic changes in inhibin messenger RNAs in rat ovarian follicles during the reproductive cycle. Science 239 1296-1299.

Woodruff TK, D’Agostino JB, Schwartz NB \& Mayo KE 1989 Decreased inhibin gene expression in preovulatory follicles requires primary gonadotropin surges. Endocrinology 124 2193-2199.

Woodruff TK, Krummen LA, Chen S, DeGuzman G, Lyon R, Baly DL, Allison DE, Garg S, Wong WL, Hebert N et al. 1993a Pharmacokinetic profile of recombinant human (rh) inhibin A and activin A in the immature rat. I. Serum profile of rh-inhibin A and rh-activin A in the immature female rat. Endocrinology 123 715-724.

Woodruff TK, Krummen L, Chen SA, Lyon R, Hansen SE, DeGuzman G, Covello R, Mather J \& Cossum P 1993 b Pharmacokinetic profile of recombinant human ( $\mathrm{rh}$ ) inhibin A and activin $\mathrm{A}$ in the immature rat. II. Tissue distribution of 
$\left[{ }^{125} \mathrm{I}\right] \mathrm{rh}$-inhibin $\mathrm{A}$ and $\left[{ }^{125} \mathrm{I}\right] \mathrm{rh}$-activin $\mathrm{A}$ in immature female and male rats. Endocrinology 132 725-734.

Woodruff TK, Besecke LM, Groome N, Draper LB, Schwartz NB \& Weiss J 1996 Inhibin A and inhibin B are inversely correlated to follicle-stimulating hormone, yet are discordant during the follicular phase of the rat estrous cycle, and inhibin A is expressed in a sexually dimorphic manner. Endocrinology 137 5463-5467.
Yokoyama Y, Nakamura T, Nakamura R, Irahara M, Aono T \& Sugino H 1995 Identification of activins and follistatin proteins in human follicular fluid and placenta. Journal of Clinical Endocrinology and Metabolism 80 915-921.

Received in final form 8 March 2002 Accepted 5 April 2002 